\title{
PENERAPAN METODE PEMBERIAN TUGAS PEMBUATAN MIND MAPPING UNTUK MENINGKATKAN MOTIVASI DAN PRESTASI BELAJAR SISWA
}

\author{
Afririo Enanda ${ }^{1}$, Moch Bruri Triyono ${ }^{2}$ \\ ${ }^{1,2}$ Jurusan Pendidikan Teknik Mesin FT UNY
}

\begin{abstract}
This study aimed to study the increase in learning motivation and academic achievement in mechanical technology subject using the mind mapping method. The research was carried out in SMK N 2 Klaten. This classroom action research was conducted in four cycles with study subjects of 35 students. Data were collected using questionnaires and exams observation sheets. Data were analyzed using quantitative descriptive. Results of this research are an average increase of student motivation by $27 \%$, in which the average score of learning motivation is only $58 \%$ in the first cycle, increase to $64 \%$ in the second cycle, and increased to $79 \%$ in the third cycle and then to $82 \%$ in the fourth cycle. For student' academic achievement, there is an increase of $68.6 \%$. In the first cycle, the average mastery learning achievement test reached only $31.4 \%$ and $82.2 \%$ at the second cycle, and then increased to $100 \%$ in third and remains $100 \%$ in the fourth cycle. Students who pass the fourth exam 4 is 35 students.
\end{abstract}

Keywords: learning motivation, academic achievement, assignment method, mind mapping.

\begin{abstract}
ABSTRAK
Penelitian ini bertujuan untuk mengetahui besarnya peningkatan motivasi dan prestasi belajar teknologi mekanik menggunakan metode pemberian tugas pembuatan mind mapping. Penelitian tindakan kelas ini dilakukan dalam empat siklus dengan subyek penelitian adalah 35 siswa. Metode pengumpulan data menggunakan angket lembar observasi dan soal ujian. Analisis data menggunakan deskriptif kuantitatif. Hasil penelitian menunjukkan bahwa ada peningkatan rata-rata motivasi belajar siswa sebesar $27 \%$ dimana skor ratarata motivasi belajar pada siklus I hanya sebesar $58 \%$ dan siklus II sebesar $64 \%$, kemudian meningkat menjadi $79 \%$ pada siklus III dan pada siklus IV menjadi $82 \%$, sedangkan untuk prestasi belajar siswa terjadi peningkatan sebesar $68,6 \%$, pada siklus I rata-rata ketuntasan tes prestasi belajar hanya mencapai $31,4 \%$ dan siklus II meningkat menjadi $82,2 \%$ kemudian meningkat menjadi $100 \%$. dan siklus IV tetap pada $100 \%$. Pada siklus IV dengan jumlah siswa yang tuntas ujian 4 mencapai 35 siswa.
\end{abstract}

Kata kunci: motivasi belajar, prestasi belajar, metode penugasan, mind mapping.

\section{PENDAHULUAN}

Hasil observasi pengamatan lapangan dan wawancara terhadap ketua Program Keahlian Teknik Pengecoran Logam diperoleh data tentang siswa, peran guru, dan motivasi belajar dan prestasi belajar siswa yang belum memuaskan. Hal ini dapat dilihat pada motivasi belajar siswa saat kegiatan belajar mengajar di kelas, masih terdapat siswa yang belum fokus dan masih mengobrol dengan teman maupun bermain telepon genggam dan juga kemampuan siswa dalam menjawab pertanyaan dari soal yang diberikan belum dapat mengerjakan dengan tepat. Terdapat faktor-faktor yang mempengaruhi motivasi belajar dan prestasi belajar siswa. Faktor tersebut antara lain faktor fasilitas pendukung belajar yang lebih efektif dan bervariasi yang digunakan dalam proses pembelajaran agar siswa tidak mudah bosan saat kegiatan belajar mengajar berlangsung. Kemudian faktor metode pembelajaran yang kurang menarik, sehingga para siswa belum sepenuhnya paham dan fokus terhadap mata pelajaran yang diajarkan. Proses kegiatan pembelajaran masih kurang efektif karena masih banyak siswa yang kurang fokus dan tidak aktif belajar dan hanya bermain gadget di kelas pada saat mata pelajaran berlangsung sehingga materi dan prestasi belajar tidak dapat diraih maksimal oleh siswa bersangkutan. 
Kurikulum 2013 yang dilaksanakan di SMK, dalam silabusnya terdapat berbagai kegiatan pembelajaran yang harus terwujud antara lain kegiatan; mengamati, menanya, pengumpulan data, mengasosiasi, dan mengomunikasikan informasi. Proses ini dikaitkan dengan penerapan metode pemberian tugas pembuatan mind mapping untuk meningkatkan motivasi belajar dan prestasi belajar siswa, bertujuan untuk mengamati pengunaan metode tersebut. Kegiatan menanya mengkondisikan agar siswa aktif dan mandiri dalam pengunaan metode yang menunjang belajar. Pengumpulan data yang dilakukan untuk mengerjakan dari pertanyaan yang didapat dan dapat menyelesaikannya. Langkah selanjutnya adalah mengasosiasi yaitu mengkategorikan data yang sudah diperoleh, kemudian disimpulkan sampai mendapat hasil yang tepat dan sesuai dan langkah terakhir adalah mengomunikasikan hasil yang didapat dan disampaikan agar membuat lebih mantap terhadap hasil dan dapat menunjukan prestasi belajar yang telah optimal.

Penjelasan di atas menunjukkan bahwa terdapat faktor-faktor yang menghambat motivasi belajar dan prestasi belajar siswa. Perlu adanya metode yang cocok dalam mengajar, sehingga dalam penelitian ini dikaji faktor-faktor tersebut agar dapat mengetahui sejauh mana pengaruhnya terhadap prestasi belajar dan motivasi belajar siswa pada teknologi mekanik.

Metode pemberian tugas bersifat mengikat kepada siswa dinggap dapat mengurangi minat siswa untuk melakukan secara jujur, model pemberian tugas bersifat kurang menarik hanya dengan mengerjakan soal-soal, mencari materi yang diluar pembelajaran hari itu akan membuat siswa merasa terikat dan tertekan, kurikulum 2013 yang mengharuskan siswa untuk bersifat aktif dan dengan kebijakan pemerintah bahwa hari efektif sekolah dikurangi menjadi 5 hari efektif dinilai mambebani apabila ditambah dengan pemberian tugas yang berlebihan. Berdasar pada beberapa akun media sosial siswa dimana keluhan tentang tugas sekolah yang menjadi beban dan waktu istirahat siswa yang tetap harus diisi dengan kegiatan akademik, namun proses pemberian tugas dinilai efektif karena proses pembelajaran hanya berjalan 5 hari mengakibatkan proses belajar menjadi sangat padat sehingga materi yang diberikan kurang optimal, hal ini mencetukan ide untuk membuat suatu metode penugasan dimana siswa tidak terbebani dengan tetap menekankan pada ketersampaian materi yang diberikan. Pemberian tugas pembuatan mind mapping dinilai efektif karena disamping memacu siswa untuk mempelajari dan mengembangkan materi yang sudah diberikan. Setyaningsih (2010) mengungkapkan bahwa penggunaan metode pemberian tugas untuk meningkatkan kompetensi siswa kelas $\mathrm{X}$ pada teknik menghias hidangan mata diklat pengolahan makanan indonesia dapat meningkatkan kompetensi siswa dalam teknik menghias makanan.

Berdasarkan pada penjelasan diatas maka penelitian ini merupakan penerapan metode pemberian tugas pembuatan mind mapping untuk meningkatkan motivasi dan prestasi belajar siswa

\section{METODE}

Jenis penelitian ini merupakan penelitian tindakan kelas (classroom action research). Suharsimi Arikunto (2007:3) menjelaskan bahwa penelitian tindakan kelas merupakan suatu pencermatan terhadap kegiatan belajar berupa sebuah tindakan, yang sengaja dimunculkan dan terjadi dalam sebuah kelas secara bersama. Subyek pada penelitian ini adalah siswa kelas X Teknik Pengecoran logam 1 SMK Negeri 2 Klaten dengan jumlah 35 siswa.

Tahapan penelitian tindakan kelas yaitu diawali dengan perencanaan tindakan (planning), diteruskan dengan pelaksanaan tindakan (action), diikuti dengan pengamatan terhadap tindakan yang dilakukan (observation) 
dan melakukan refleksi (reflecting) (Kemmis Taggart:1988)

Teknik pengumpulan data menggunakan lembar observasi, angket aspek motivasi dan soal tes prestasi belajar siswa yang dikerjakan siswa di setiap akhir siklus. Analisis data yang digunakan adalah analisis data deskriptif kuantitatif. Penjabaran teknik analisis data sebagai berikut motivasi belajar siswa dianalisis untuk mengetahui persentase skor motivasi. Menentukan kriteria pemberian skor terhadap masing-masing indikator pada setiap aspek motivasi yang diamati (Hamzah B. Uno: 2008). Menjumlahkan skor untuk masing-masing aspek motivasi yang diamati. Menghitung skor motivasi pada setiap aspek dengan menggunakan Persamaan 1 dan 2.

$$
\begin{gathered}
\text { skor motivasi } \\
=\frac{\frac{\text { skor angket }}{2}+(\text { skor lembar observasi } X 2)}{10} \\
\%=\frac{\text { skor motivasi siswa }}{\text { skor maksimum }} \times 100 \%
\end{gathered}
$$

Analisis tes hasil belajar digunakan untuk mengukur hasil belajar pengetahuan dan ketrampilan siswa selama mengikuti dengan menggunakan metode pemberian tugas pembuatan mind mapping. Analisis terhadap tes hasil belajar siswa dilakukan dengan analisis kuantitatif yaitu menentukan rata-rata nilai tes. Jumlah siswa yang berhasil mencapai KKM, selanjutnya dihitung persentasenya.

\section{HASIL DAN PEMBAHASAN}

Selama proses pembelajaran berlangsung peneliti menggunakan metode pemberian tugas pembuatan mind mapping dengan pelaksanaan pembelajaran menggunakan empat siklus yaitu siklus I, siklus II, siklus III dan siklus IV. Setiap siklus dalam penelitian tindakan kelas ini terdiri dari beberapa tahap yang terdiri dari tahap perencanaan, pelaksanaan, observasi, dan refleksi.

Berdasarkan paparan hasil penelitian yang telah dilakukan terhadap siswa kelas $\mathrm{X}$ teknik pengecoran logam pada mata pelajaran teknologi mekanik, maka dapat diketahui adanya peningkatan motivasi belajar dan prestasi belajar siswa dengan penerapan metode pemberian tugas pembuatan mind mapping.

Hasil pengamatan motivasi belajar, semua aspek motivasi belajar siswa telah mencapai kriteria keberhasilan yaitu $75 \%$. Peningkatan rata-rata motivasi belajar yang diperoleh pada siklus I dan siklus II meningkat $7 \%$ dan dari siklus II ke siklus III meningkat $15 \%$. Rata-rata motivasi belajar yang diperoleh pada siklus I sebesar 58\%, untuk siklus II sebesar 64\% untuk siklus III sebesar 79\% dan meningkat menjadi $82 \%$ pada siklus IV .

Aspek yang pertama yaitu siswa aktif bertanya kepada guru ataupun rekan,terjadi peningkatan skor motivasi belajar ditunjukkan dari data observasi motivasi belajar siswa yaitu: pada siklus I sebesar 40,57\%, siklus II sebesar $40,57 \%$, siklus III sebesar $66,9 \%$ dan meningkat menjadi 70,29\% pada siklus IV.

Aspek yang kedua yaitu Siswa membuat suatu ringkasan (mind mapping) dari materi yang diberikan, terjadi peningkatan skor motivasi belajar ditunjukkan dari data observasi motivasi belajar siswa yaitu: pada siklus I sebesar 47,43\%, siklus II sebesar 56,86\%, siklus III sebesar $100 \%$ dan meningkat menjadi $100 \%$ pada siklus IV.

Aspek yang ketiga yaitu siswa merespon tanggapan dari rekan lain, dengan cara pemberian suatu solusi dari problem yang ditanyakan, terjadi peningkatan skor motivasi belajar ditunjukkan dari data observasi motivasi belajar siswa yaitu pada siklus I sebesar $48 \%$, siklus II sebesar 54,86\%, siklus III sebesar $60 \%$ dan meningkat menjadi $62,29 \%$ pada siklus IV.

Aspek yang keempat yaitu siswa merespon dengan menjawab, saat guru memberikan suatu pertanyaan, terjadi peningkatan skor motivasi belajar ditunjukkan dari data observasi motivasi belajar siswa yaitu: pada siklus I sebesar $48 \%$, siklus II sebesar $54,86 \%$, siklus III sebesar $60 \%$ dan meningkat menjadi $62,29 \%$ pada siklus IV. 
Aspek yang kelima yaitu Siswa mengerjakan tugas membuat dan memperbaiki ringkasan (mind mapping) yang diberikan guru, terjadi peningkatan skor motivasi belajar ditunjukkan dari data observasi motivasi belajar siswa yaitu: pada siklus I sebesar 37,71\%, siklus II sebesar $56,86 \%$, siklus III sebesar $66,9 \%$ dan meningkat menjadi $80 \%$ pada siklus IV.

Aspek yang keenam yaitu kehadiran siswa tepat waktu, skor motivasi belajar ditunjukkan dari data observasi motivasi belajar siswa yaitu pada siklus I sebesar $100 \%$, siklus II sebesar $100 \%$, siklus III sebesar $100 \%$ dan meningkat menjadi $100 \%$ pada siklus IV.

Peningkatan motivasi belajar siswa pada tiap pertemuan yang dibagi ke dalam empat siklus membuktikan bahwa penerapan metode pemberian tugas pembuatan mind mapping dapat menjadi alternatif untuk memvariasi metode pembelajaran yang biasa digunakan, dengan tujuan agar siswa bisa mendorong siswa untuk berperan aktif dalam pembelajaran.

Histogram peningkatan motivasi belajar siswa pada setiap aspek lembar observasi dan rata-rata motivasi belajar siswa dapat dilihat pada Gambar 1 dan Gambar 2.

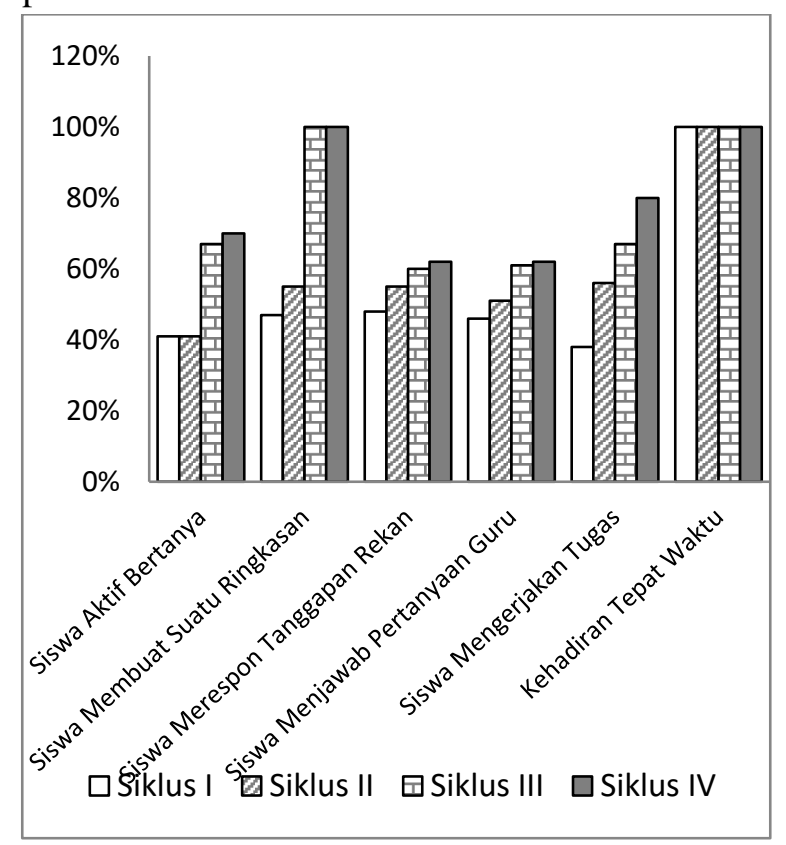

Gambar 1. Histogram Aspek Lembar Observasi Motivasi Siswa Siklus I-IV

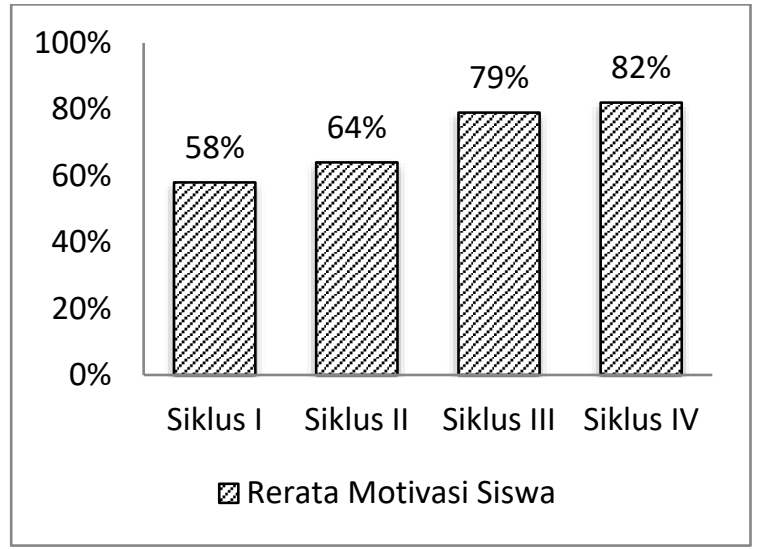

Gambar 2. Histogram Rata-Rata Motivasi Siswa Siklus I-IV

Gambar di atas menunjukkan bahwa penerapan metode pemberian tugas pembuatan mind mapping dapat meningkatkan motivasi belajar siswa. Hal itu terlihat bahwa motivasi belajar siswa terjadi peningkatan dari siklus I, siklus II, siklus III dan siklus IV.

Peningkatan prestasi belajar siswa diperoleh berdasarkan hasil tes yang diberikan pada setiap akhir siklus. Hasil pada siklus I dapat dikatakan bahwa dari 35 siswa terdapat 11 siswa yang dinyatakan tuntas dengan memperoleh nilai $\geq 70$, sedangkan yang belum tuntas sebanyak 24 siswa karena nilai yang diperoleh belum memenuhi KKM (kriteria ketuntasan minimal) yang ditentukan sekolah yaitu 70. Pada siklus II siswa yang dinyatakan tuntas dengan nilai $\geq 70$ meningkat menjadi 29 siswa dan siswa yang belum tuntas sebanyak 6 siswa. Kemudian pada siklus III siswa yang dinyatakan tuntas dengan nilai $\geq 70$ meningkat dari siklus sebelumnya menjadi 35 siswa. pada siklus IV siswa yang dinyatakan tuntas dengan nilai $\geq 70$ tetap pada siklus sebelumnya yaitu $100 \%$ siswa tuntas menjadi 35 siswa.

Hasil tes juga menunjukkan adanya peningkatan nilai rata-rata siswa, yang mulanya pada siklus I sebesar 66, pada siklus II sebesar 76, pada siklus III sebesar 82 dan menurun menjadi 79 pada siklus IV. Rata-rata ketuntasan belajar siswa juga mengalami peningkatan yaitu: pada siklus I sebesar $31,42 \%$, pada siklus II sebesar $82,8 \%$, pada siklus III sebesar $100 \%$ dan pada siklus IV tetap sebesar $100 \%$. 
Histogram peningkatan ketuntasan belajar yang dicapai siswa dan nilai rata-rata tes prestasi belajar siswa dapat dilihat pada Gambar 3 dan Gambar 4.

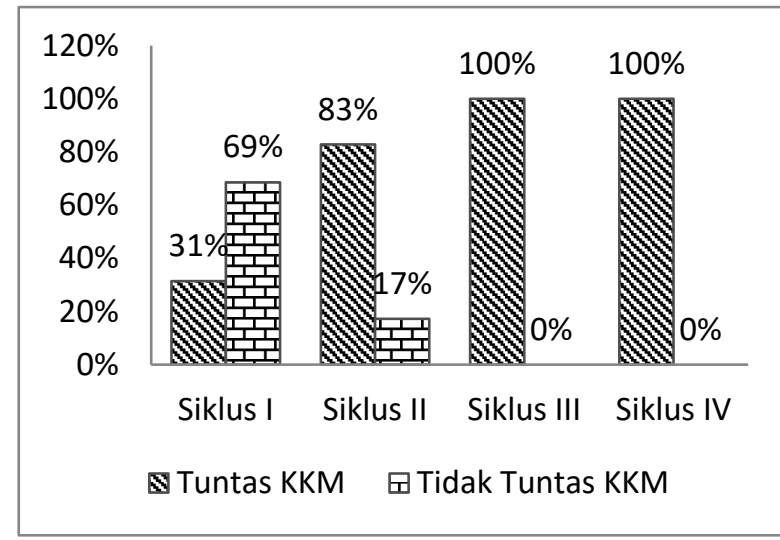

Gambar 3. Histogram Ketuntasan Tes Prestasi Belajar Siswa Siklus I-IV

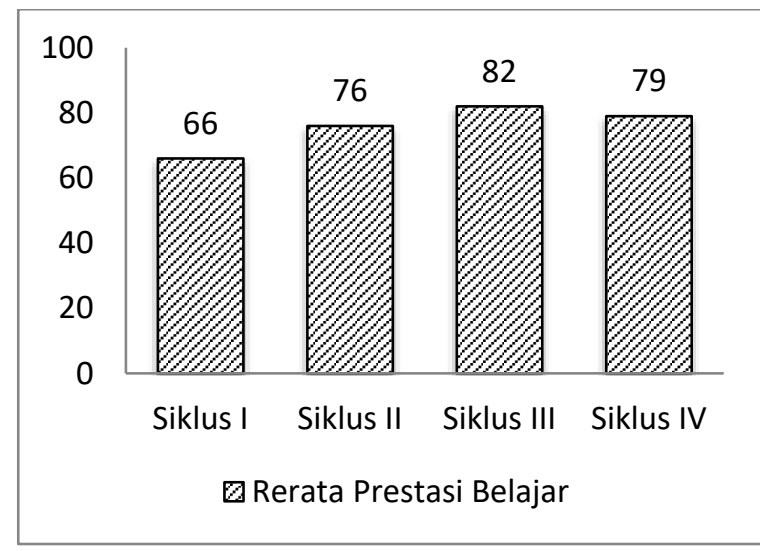

Gambar 4. Histogram Rata-Rata Nilai Tes Prestasi Belajar Siswa Siklus I-IV

\section{SIMPULAN}

Hasil penelitian dan pembahasan di atas dapat disimpulkan sebagai berikut: (a) Penerapan metode pemberian tugas pembuatan mind mapping dapat meningkatkan motivasi belajar siswa kelas. Hasil pengamatan menunjukkan bahwa terjadi peningkatan motivasi belajar sebesar $24,41 \%$ dimana skor rata-rata motivasi belajar pada siklus I sebesar $57,54 \%$, siklus II 64,04\%, siklus III sebesar $78,7 \%$ dan pada siklus IV meningkat menjadi $81,95 \%$. (b) Penerapan metode pembelajaran menggunakan metode pemberian tugas pembuatan mind mapping dapat meningkatkan prestasi belajar siswa. Prestasi belajar siswa mengalami peningkatan dari siklus I, siklus II, siklus III dan siklus IV telah mencapai indikator keberhasilan yaitu $\geq 75 \%$ ketuntasan tes prestasi belajar siswa, hasil tes prestasi belajar siswa menunjukkan bahwa terjadi peningkatan prestasi belajar siswa sebesar 68,6\%. Ketuntasan KKM pada siklus I sebesar 31,42\%, pada siklus II sebesar $82,8 \%$, pada siklus III sebesar $100 \%$ dan pada siklus IV tetap sebesar $100 \%$.

Beberapa saran atas hasil penelitian di atas adalah: sebaiknya guru menerapkan metode pembelajaran yang bervariasi untuk meningkatkan motivasi dan prestasi belajar peserta didik, guru selalu memberikan motivasi dan mampu menciptakan suasana pembelajaran yang aktif dan kondusif sehingga tercipta pembelajaran yang aktif dengan komunikasi dua arah yang dapat meningkatkan motivasi belajar siswa.

\section{DAFTAR RUJUKAN}

Endang Mulyatiningsih. 2011. Riset Terapan: Bidang Pendidik \& Teknik. Yogyakarta: UNY Press.

Hamzah B. Uno. 2008. Teori Motivasi dan Pengukurannya. Jakarta: PT. Bumi Aksara

Kemmis,S. and Mc Taggert, R. 1988. The Action Research Planner,Third Edition. Victoria: Deakin University.

Saifudin Azwar. 1998. Tes Prestasi (Fungsi dan Pengembangan Pengukuran Prestasi Belajar) Yogyakarta: Pustaka Pelajar

Suharsimi Arikunto. 2007. Penelitian Tindakan Kelas. Jakarta: PT. Bumi Aksara

Setyaningsih. 2010. Metode pemberian tugas untuk meningkatkan kompetensi siswa kelas X pada teknik menghias hidangan. Skripsi, tidak dipublikasikan. Universitas Negeri Yogyakarta 